\title{
Pemberian Makanan Sehat "Nutrisi Seluler" terhadap Produktivitas Kerja pada Karyawan Penggilingan Padi
}

\author{
Aprina \\ Jurusan Keperawatan, Politeknik Kesehatan Tanjungkarang \\ Email: aprinamurhan@yahoo.co.id
}

\begin{abstract}
Feeding Healthy Food "Cellular Nutrition" to Work Productivity at Rice Milling Employees. The current diet of various cultural influences, technology, lifestyle greatly affects human health in general in various countries. According to WHO statistics, $70 \%$ of premature deaths, caused by diabetes, cancer, heart attack and stroke, $50 \%$ are associated with poor diet or lack of nutrition. Rice millers began to stand in 1980, from the beginning employ 10-15 employees per day, if there is a demand to grind 20 tons of rice per day then the workforce increases to meet the target to 40 workers per day. The purpose of this research is to know the effect of Nutrition Cellular on the productivity of rice mill worker of HANESCA Subdistrict of Purbolinggo East Lampung. Design of experimental research with nonrandomized design Pre Test Post Test Contro Group Design, research sample examined physical condition, selected from labor that has been measured IMT with the number of 15 respondents. The statistical test used in this study is a dependent $t$-test that aims to examine the differences between the two treatment groups before and after the administration of Nutrition Cellular. The result of research Average of work productivity of employees before given Nutrition Cellular equal to 5910,53, average work productivity of employees after given Cellular Nutrition equal to 6,784 kg per day, there is an effect of Nutrition Cellular to employee work productivity $\mathrm{p}$-value value 0,041 . Suggestions that the company can cultivate healthy food Nutrition Cellular as a source of nutrients can be followed by all companies both public and private because it is very good to provide energy and protein that has met the needs of labor.
\end{abstract}

Keywords: Nutrition cellular, Work productivity

\begin{abstract}
Abstrak: Pemberian Makanan Sehat "Nutrisi Seluler" terhadap Produktivitas Kerja pada Karyawan Penggilingan Padi. Pola makan saat ini berbagai pengaruh budaya, teknologi, gaya hidup sangat mempengaruhi kesehatan manusia secara umum di berbagai negara. Menurut statistik WHO 70\% kematian dini, disebabkan oleh penyakit diabetes, kanker, serangan jantung dan stroke, $50 \%$ berhubungan dengan pola makan yang tidak baik atau kekurangan nutrisi. Penggilingan padi mulai berdiri tahun 1980, sejak awal memperkerjakan karyawan tetap 10-15 orang per hari, bila ada permintaan menggiling 20 ton beras perhari maka tenaga kerja bertambah untuk memenuhi target sampai 40 tenaga kerja per hari. Tujuan penelitian mengetahui pengaruh Nutrition Cellular terhadap produktivitas kerja karyawan penggilingan padi HANESCA Kecamatan Purbolinggo Lampung Timur. Desain penelitian eksperimen dengan rancangan non randomized Pre Test Post Test Contro Group Desain, sampel penelitian diperiksa kondisi fisiknya, dipilih dari tenaga kerja yang sudah diukur IMT dengan jumlah 15 responden. Uji statistik yang digunakan dalam penelitian ini adalah Uji t dependen yang bertujuan untuk menguji perbedaan antar dua kelompok perlakuan sebelum dan sesudah pemberian Nutrition Cellular. Hasil penelitian Rata-rata produktivitas kerja karyawan sebelum diberikan Nutrition Celluler sebesar 5910,53, rata-rata produktivitas kerja karyawan sesudah diberikan Nutrition Cellular sebesar 6,784 kg per hari, ada pengaruh Nutrition Cellular terhadap produktivitas kerja karyawan nilai p-value 0,041. Saran agar perusahaan dapat membudidayakan makanan sehat Nutrition Cellular sebagai sumber zat gizi dapat diikuti oleh semua perusahaan baik negeri maupun swasta, karena sangat baik untuk memberikan energi dan protein yang telah memenuhi kebutuhan tenaga kerja.
\end{abstract}

Kata kunci: Nutrition cellular, Produktivitas kerja

Keadaan gizi dan kesehatan yang optimal berguna sebagai dasar pencapaian tingkat perkembangan fisik dan intelektualitas serta produktivitas yang tinggi. Rendahnya produktivitas kerja ada hubungan baik langsung maupun tidak langsung dengan anemia gizi di Indonesia (Moehji, 2009).

Pada orang dewasa yang anemia ditemukan kemampuan fisik kerja rendah, tidak mampu bekerja keras, mudah letih, kurang berinisiatif. Pemberian makanan tradisional 
Lampung "Serwit", yang telah dapat meningkatkan produktivitas kerja lima kali lipat hasil petik bibit nanas sesudah makan serwit tersebut (Rickum Djelita, 2005). Tubuh memerlukan berbagi zat dari makanan untuk pemeliharaan tubuh, perbaikan jarimgan pertumbuhan dan segala kerusakan dari sel. Demikian juga pekerjaan memerlukan tenaga yang sumbernya adalah menyajikan nutrisi optimal yang mudah dicerna, diserap dan dipergunakan oleh sel-sel tubuh.

Pola makan saat ini dengan berbagai pengaruh budaya, teknologi, gaya hidup sangat mempengaruhi kesehatan manusia secara umum diberbagai negara (Azwar, 2004). Menurut statistik WHO, 70\% kematian dini disebabkan oleh penyakit diabetes, kanker, serangan jantung dan stroke. Kematian dini di atas $50 \%$ diantaranya berhubungan dengan pola makan yang tidak baik atau kekurangan nutrisi. Diperkirakan 7 dari 10 cek kesehatan yang dilakukan seseorang ke dokter biasanya ada gangguan yang berhubungan dengan pola makan yang tidak baik (Kardjati, 2009). Makanan sehat (Nutrisi Seluler) merupakan program gizi yang dirancang agar sel-sel tubuh yaitu bagian terkecil yang hidup dalam tubuh mendapat gizi seoptimal mungkin untuk tumbuh, memperbaiki diri/ rehenerasi sel dan melaksanakan fungsi, tugas masing-masing sel sebaik mungkin untuk mencapai kesehatan maksimal.

Maka perkuat sistem kekebalan tubuh anda dengan nutrisi seluler. Pada dasarnya kita adalah makhluk hidup yang tersusun lebih dari 100 triliun sel, setiap sel memiliki serangkaian reaksi kimia sehingga membutuhkan energi dan nutrisi. Jika konsumsi makanan rendah nutrisi, kerja sel menjadi lamban dan otomatis kekebalan tubuh melemah misalnya sel hati anda kurang nutrisi, maka tidak mampu memproses racun secara efesien, sebagai salah satu fungsi tugas sel-sel hati dan badan akan merasa letih. Juga sel nutrisi, akan menjadikan badan lambat bereaksi seperti lampu yang meredup dan bila sel otot kurang nutrisi maka badan akan merasa lemas.

Pada kondisi demikian, tentu saja tubuh tidak mampu melawan serangan berbagai penyakit, maka makanlah nutrisi yang cukup lengkap untuk sel-sel tubuh, sehingga sistem kekebalan tubuh meningkat (Kurniawan, 2009.). Melalui makanan nutrisi seluler bahan-bahan bergizi yang menyehatkan membantu memelihara sel-sel tubuh dengan campuran istimewa nutrisi tumbuhan yang mengandung vitamin, antioksidan dan mineral untuk membantu fungsi sel.
Penelitian sebelumnya tentang "Serwit", telah bermakna meningkatkan produktivitas kerja maka peneliti ingin meneliti nutrisi makro dan mikro yang lengkap pada tingkat sel, sehingga tubuh dapat berfungsi secara optimal dan terjadi perbaikan vili-vili usus, penyerapan gizi optimal serta regenerasi sel-sel yang lebih sehat.

Geografis Provinsi Lampung seluas $35.400 .25 \mathrm{~km}$, dengan ibukota adalah Bandar Lampung, merupakan penyatuan dua kota yaitu tanjung karang dan teluk betung (Dinkes Provinsi Lampung, 2014). Penduduk provinsi lampung berjumlah 7.074.999 jiwa semua tenaga kerja belum mendapatkan Nutrition cellular yang merupakan program pengendalian berat badan. Penggilingan padi mulai berdiri tahun 1980 . Penggilingan padi sejak awal memperkerjakan karyawan tetap 10-15 orang perhari, bila ada permintaan dari dolog tenaga kerja bertambah untuk memenuhi target sampai 40 tenaga kerja per hari. Adapun pada waktu permintaaan dolog tersebut menggiling 20 tonberas per hari. Berdasarkan hasil di atas maka peneliti memillih lokasi tersebut untuk di teliti agar dapat disesuaikan dengan program pengendalian berat badan sehingga produktifitas tenaga kerja meningkat. Tujuan penelitian ini adalah untuk mengetahui pengaruh nutrision cellular terhadap produktifitas kerja karyawan penggilingan padi HANESCA kecamatan purbolinggo lampung timur.

\section{METODE}

Jenis penelitian kuantitatif, rancangan penelitian eksperimen dengan rancangan non frandomized pre test. Post test control group desain.

Tempat penelitian dilakukan pada karyawan penggilingan padi HANESCCA Kecamatan Purbolinggo Lampung Timur. Waktu penelitian bulan Juli sampai dengan November 2015. Populasi penelitian adalah karyawan penggilingan padi HANESCA Kecamatan Purbolinggo Lampung Timur. Teknik pengambilan sampel penelitian total populasi, responden diperiksa kondisi fisiknya, sedangkan sampel dipilihdari tenaga kerja yang sudah diukur IMT dengan jumlah 15 responden, kriteria inklusi responden sebagai berikut: jenis kelamin laki-laki, umur 20-40 tahun, tenaga kerja tersebut mendapat makan atau uang makan dari perusahaan, dan tenaga kerja tersebut tidak dalam keadaan absen selama dalam penelitian, responden bersedia menandatangani informed concent (persetujuan penelitian). 
Variabel independent pemberian nutrition cellular (NC) diberikan dengan cara: NC 1 kali (siang) selama 3 hari kerja. Makanan sehat yangtelah dipersiapkan 2 sendok makan yang sesuai dengan keperlusn tubuh untuk satu kali disantap = makan 2 piring nasi dengan lauk pauk TKTP. Variabel dependent, yang terdiri dari produktivitas karyawan penggilingan padi HANESCA dihitung sebelum pemberian $\mathrm{NC}$ selama seminggu dan sesudah pemberian $\mathrm{NC}$ selama 3 hari kerja. Variabel kendali BB, TB, Kadar lemak, IMT, Tensi. Kelima variabel kendali diukur pre dan post NC. Status gizi dengan pengukuran IMT oleh peneliti sebelum dan sesudah NC. Instrumen, kuesioner untuk data responden; usia, tahun lahir, tahun masuk kerja, lama kerja, pendidikan, riwayat kerja, jumlah pengilingan padi dan angka absen. Kuesioner pola makan (dietectic form) untuk menghitung masuk makanan sehari selama 24 jam. Alat-alat untuk pemeriksaan tensi timbangan, OMRON untuk mengukur lemak. Tabel untuk pemeriksaan: BB, TB, IMT, Kadar Lemak, Tensi. Cara pengumpulan data wawancara perorangan dilakukan dengan kuesioner. BB, TB, produktivitas kerja, IMT, Kadar lemak, Tensi (pre dan post NC). Proses pengolahan data dilakukan melalui 4 (empat) tahapan yaitu: editing, coding, proccesing, dan cleaning (Hastono, 2007). Analisa data pada penelitian ini adalah analisa univariat dan bivariat. Analisa univariat dilakukan untuk melihat gambaran masing-masing variabel yang diteliti baik variabel dependen maupun variabel independen. Analisa bivariat dilakukan uji statistik yang digunakan dalam penelitian ini adalah uji $\mathrm{T}$.

\section{HASIL}

Tabel 1. Distribusi Responden Menurut Umur, Lama Kerja, BB, TB, Produktivitas Gilingan, Kl, IMT, BMR dan Tekanan Darah

\begin{tabular}{|c|c|c|c|}
\hline Variabel & $\begin{array}{c}\text { Mean } \\
\text { Median }\end{array}$ & SD & $\begin{array}{l}\text { Min- } \\
\text { Maks }\end{array}$ \\
\hline Umur & $\begin{array}{l}34,40 \\
33,00 \\
\end{array}$ & 8,936 & $22-50$ \\
\hline Lama kerja & $\begin{array}{r}3,53 \\
4,0\end{array}$ & 2,850 & $0-8$ \\
\hline $\begin{array}{l}\text { Berat badan sebelum } \\
\text { NC }\end{array}$ & $\begin{array}{l}57,00 \\
59,00\end{array}$ & 7,163 & $45-69$ \\
\hline $\begin{array}{l}\text { Berat badan sesudah } \\
\text { NC }\end{array}$ & $\begin{array}{l}57,20 \\
59,00\end{array}$ & 7,15 & $46-70$ \\
\hline $\begin{array}{l}\text { Produktivitas } \\
\text { gilingan sebelum NC }\end{array}$ & $\begin{array}{l}5910,53 \\
6784,00\end{array}$ & 4755,02 & $0-1282$ \\
\hline $\begin{array}{l}\text { Produktivitas } \\
\text { sesudah NC }\end{array}$ & $\begin{array}{l}7206,93 \\
7840,00\end{array}$ & 3161,25 & $0-9945$ \\
\hline KI sebelum NC & $\begin{array}{l}15,30 \\
14,60\end{array}$ & 6,611 & $6,8-28,6$ \\
\hline KI sesudah NC & $\begin{array}{r}16,987 \\
16,30 \\
\end{array}$ & 6,10 & $5,2-27,4$ \\
\hline IMT sebelum NC & $\begin{array}{l}22,00 \\
22,20 \\
\end{array}$ & 1,778 & $18,5-24,5$ \\
\hline IMT sesudah NC & $\begin{array}{l}22,06 \\
22,20\end{array}$ & 2,457 & $17,9-27,7$ \\
\hline BMR sebelum NC & $\begin{array}{l}1397,47 \\
1314,00\end{array}$ & 243,746 & $\begin{array}{r}1115- \\
2177\end{array}$ \\
\hline BMR sesudah NC & $\begin{array}{l}1410,73 \\
1409,00\end{array}$ & 240,55 & $\begin{array}{r}1132- \\
2175\end{array}$ \\
\hline $\begin{array}{l}\text { Tekanan darah } \\
\text { systole sebelum NC }\end{array}$ & $\begin{array}{l}114 \\
120\end{array}$ & 1,245 & $90-130$ \\
\hline $\begin{array}{l}\text { Tekanan darah } \\
\text { systole sesudah NC }\end{array}$ & $\begin{array}{l}114 \\
110\end{array}$ & 1,040 & $90-130$ \\
\hline
\end{tabular}

Dari tabel di atas terlihat bahwa rata-rata umur responden 34,40 tahun, lama kerja 3,53 tahun, BB sebelum pemberian NC 57,20 kg, BB sesudah pemberian $\mathrm{NC} 57 \mathrm{~kg}$, rata-rata produktivitas gilingan padi sebelum pemberian NC 5910,53 ton, rata-rat produktivitas gilingan padi sesudah pemberian NC 7206,93 ton, IMT responden sebelum pemberian NC22,00, IMT responden sesudah pemberian NC 22060, BMR sebelum pemberian NC 1397,47, BMR sesudah pemberian NC 1410,73, rata-rata tekanan darah systole responden sebelum pemberian NC 114 mmhg, rata-rata tekanan darah systole sesudah pemberian NC 110 mmhg. 
Tabel 2. Distribusi Rata-Rata Produktivitas Hasil Gilingan Padi Responden Menurut Pengukuran Pertama dan Kedua

\begin{tabular}{lccccc}
\hline \multicolumn{1}{c}{ Variabel } & Mean & SD & SE & $\begin{array}{c}p- \\
\text { value }\end{array}$ & n \\
\hline Produktivitas: & & & & & \\
Pengukuran I & 5910,53 & 4755,02 & 1227,74 & 0,041 & 15 \\
Pengukuran II & 6784,00 & 3161,25 & 816,233 & & \\
\hline
\end{tabular}

Dari tabel di atas terlihat bahwa rata-rata produktivitas gilingan padi responden sebelum diberikan NC 5910,53, dengan standar deviasi 4755,02. Pada pengukuran keua didapat rata-rata hasil gilingan padi responden 6784,00 dengan standar deviasi 3161,25. Terlihat nilai mean perbedaan antara pengukuran pertama dan kedua adalah 763,47. Hasil uji statistik didapatkan nilai $p$ 0,04. Artinya ada pengaruh pemberian NC terhadap produktivitas penggilingan padi karyawan.

\section{PEMBAHASAN}

Hasil rata-rata produktivitas gilinganpadi menunjukan sebelum pemberian NC lebih rendah bila dibandingkan dengan produktivitas gilingan padi setelah pemberian NC. Hasil produktivitas penggilingan padi setelah pemberian $\mathrm{NC}$ lebih tinggi dari sebelum pemberian NC. Hasil pengujian $\mathrm{t}$ hitung menunjukan ada perbedaan roduktivitas gilingan padi sebelum dan sesudah pemberian $\mathrm{NC}$ dengan nilai $p$-value 0,041 . Hasil secara deskriptif menunjukan bahwa pemberian NC dapat meningkatkan produktivitas pekerja gilingan padi Hanesca kecamatan purbolinggo lampung timur. Produktivitas menunjukan peningkatan yang signifikan sebelum dan sesudah pemberian NC.

Hasil penelitian ini juga membuktikan bahwa kandungan gizi yang dimiliki NC cukup baik sebagai sumber energi bagi para ekerja yang melakukan pekerjaan. Penelitian ini dapat digunakan dan diisyaratkan sebagai gizi pekerja untuk mengatasi permasalahan gizi kerja yang selama ini belum diadakan penelitian tentang gizi kerja.

Dalam penelitian ini tercatat ada beberapa keunggulan makanan NC. Pertama adalah kandungan energinya yang disesuaikan dengan intake pekerja. Kedua adalah kemampuannya dalam memberikan suplai mineral fe dalam tubuh. Kemanfaatan yang beragam ini disebabkan dari bervariasinya bahan makanan yang ada dalam NC, yang jumlahnya 29 macam, seyogyanya per hari 45 macam gizi yang kita santap.
Semua makanan yang diberikan selama NC tersebut disesuaikan hasil pengukuran IMT dengan rumus Haris Benedi'c. dalam penyajian NC dengan sekali olah menjadi sebuah makanan sehat yang dapat diperoleh manfat yang cukup lengkap yaitu kandungan Nutrition Cellular diantaranya adalah protein kedelai: protein diet yang berguna untuk memperbaiki dan memelihara pertumbuhan setiap sel dalam tubuh, vitamin A: diperlukan untuk mata, perkembangan tulang dan pertumbuhan, vitamin $\mathrm{D}$, vitamin $\mathrm{E}$, tiamin, reboflafin, niasin, vitamin $\mathrm{B} 6$, vitamin B12, pentothenic acid, calcium, zat besi, fosfor, magnesium, seng, Iodin, potasium, tembaga, selenium, mangan, serat gandum, energi, protein, lemak, karbohidrat, fe, vitamin dan mineral (Almatsier, 2010).

Hal yang istimewa dalam NC adalah protein dari keelai yang tidak mengandung purin, sangat baik dan aman untuk penderita asam urat dan rotein yang paling tinggi manfaatnya karena tidak mengandung lemak. Protein sangat baik untuk penderita kanker, ostheoporosis, menurunkan kadar kolestrol baik untuk jantung dan menyeimbangkan hormon dalam tubuh. Campuran bahan-bahan alami termasuk protein, karbohidrat, vitamin dan mineral. Sangat baik bagi penderita diabetes melitus karena mengandung fructose. Keperluan tubuh $70 \%$ akan vitamin dan mineral berasal dari nutrisi shake mengandung anti oksidan. Pemyembuhan kanker usus, meningkatkan keawetan tulang, baik sebagai sumber protein pada penyakit ginjal, menurunkan kelelahan, meningkatkan kekebalan tubuh, memperbaiki memori, sebagai bahan bakar tubuh, membuat tubuh merasakenyang dan berenergi, merubah ola makan menjadi lebih sehat dan seimbang, mencegah banyak pengaruh buruk pada pola makan yang tidak baik, buang air besar lebih lancar, terbiasa dengan makanan nabati, kulit lebih cerah, memulai proses regenerasi sel-sel yang lebih sehat, terbiasa mengkonsumsi air putih dalam jumlah yang cukup, sel tubuh lebih kuat dan berfungsi efektif (Arisman, 2004).

\section{SIMPULAN}

Penelitian ini memberikan hasil kesimpulan sebagai berikut:

1. Rata-rata produktivitas kerja karyawan penggilingan padi HANESCA Kecamatan Purbolinggo Lampung Timur sebelum diberikan Nutrition Cellular sebesar 5910,53 . 
2. Rata-rata produktivitas kerja karyawan penggilingan padi HANESCA Kecamatan Purbolinggo Lampung Timur sudah diberikan Nutrition Cellular sebesar 6,784 $\mathrm{kg}$ per hari

3. Ada pengaruh Nutrition Cellular terhadap produktivitas kerja karyawan penggilingan padi HANESCA Kecamatan Purbolinggo Lampung Timur dengan nilai p-value 0,041 .

\section{SARAN}

1. Untuk perusahaan agar dapat membudidayakan makanan sehat Nutrition

\section{DAFTAR PUSTAKA}

Almatsier, Sunita. 2010. Prinsip Dasar Ilmu Gizi, Jakarta: PT. Gramedia Pustaka Utama.

Arisman. 2004. Gizi dalam Daur Kehidupan, Buku Ajar Ilmu Gizi. Cetakan 1. Jakarta: Penerbit Buku Kedokteran, EGC.

Azwar, Azrul, 2004. Kebijakan Pelayanan Kesehatan Kerja di Era Desentralisasi, Konvensi Nasional Kesehatan Kerja, Jakarta: Dep Kes RI.

Dinkes Provinsi Lampung. 2014. Profil Kesehatan Provinsi Lampung. Lampung.

Hastono, Sutanto. 2007. Analisis Data Kesehatan. Jakarta: Universitas Indonesia.

Kardjati, Sri. 2009. Nutrisi Adekuat Pendukung Kerja Fisik. Pelatihan
Cellular sebagai sumber zat gizi dapat diikuti oleh semua perusahaan baik negara maupun swasta, karena sangat baik untuk memberikan energi dan protein yang telah memenuhi keperluan tenaga kerja.

2. Perlu pendidikan dan penyuluhan kesehatan gizi agar masyarakat sadar gizi yang dapat meningkatkan produktivitas kerja yang sesuai yaitu program perbaikan gizi dan keselamatan kerja.

3. Perlu dilakukan penelitian lebih lanjut dengan menggunakan jenis makanan sehat lain terhadap pekerja dengan variasi jenis pekerjaan yang lain.

Hiperkes \& Keselamatan Kerja sebagai Dokter Perusahaan. FK Unair.

Kurniawan. A, Dariana D. Mulyati. Y. 2009. Peran Gizi bagi Pekerja. Warta Kesehatan Kerja, Edisi 1.

Moehji, Syahmien. 2009. Ilmu Gizi Penanggulangan Gizi Buruk, Bharatara. Jakarta: Penerbit Paposinar Sinanti.

Rickum, Djelita. 2005. Pengaruh Pemberian Makanan Tradisional "Serwit" Terhadap Produktivitas Kerja Karyawan, Petik Bibit Nanas I PT Great Giant Peneapple I. Doctoral Disertasi, Terbanggi Provinsi Lampung.

World Health Organization. 2010. Data and Statistics of Stroke 2010. 